\title{
7. SEDIMENT LITHOSTRATIGRAPHY OF THE GALAPAGOS HYDROTHERMAL MOUNDS ${ }^{1}$
}

\author{
Peter E. Borella, ${ }^{2}$ Deep Sea Drilling Project, University of California, La Jolla, California
}

\begin{abstract}
The hydrothermal sediments in the Galapagos mounds area are localized and essentially restricted to the mounds. Hydrothermal nontronites are interbedded with pelagic sediment, which indicates that hydrothermal activity is episodic. The nontronites are thickest on the mounds, thinning away from them rapidly and extending no more than 50 to 60 meters from a mound in any direction. The nontronites also are confined vertically to within the upper one-half to two-thirds of the cores. Manganese-oxide crust fragments are more localized than are the nontronites and do not form any continuous layer.

The lack of pelagic sediments on the mounds, the presence of nontronitic mottled zones adjacent to hydrothermal sediment layers (both vertically and laterally), the decrease of siliceous fossil content, and the presence of mostly gradational boundaries between nontronite and pelagic sediment layers suggest that hydrothermal solutions are continually invading and cannibalizing the host pelagic sediment. Replacement and dissolution of pelagic sediment along with direct precipitation of hydrothermal sediments account for the distribution of sediments on a mound.

A "relict" brown oxidized surface layer is found at 7 meters sub-bottom and can be correlated from hole to hole. I suggest that this layer is the prominent regional acoustic reflector reported by Lonsdale (1977). The combination of low carbonate accumulation and enrichment of diagenetic $\mathrm{Fe}$ and $\mathrm{Mn}$ in this zone is probably responsible for altering the acoustic impedance.
\end{abstract}

\section{INTRODUCTION}

\section{Regional Setting}

The Galapagos hydrothermal mounds area (Fig. 1) was first discovered in 1972 on a "deep-tow" survey conducted by Klitgord and Mudie (1974). The mounds field occurs in an area 18 to $32 \mathrm{~km}$ south of the Galapagos Rift between $86^{\circ} 05^{\prime} \mathrm{W}$ and $86^{\circ} 08^{\prime} \mathrm{W}$ longitude and $0^{\circ} 36^{\prime} \mathrm{N}$ and $0^{\circ} 37^{\prime} \mathrm{N}$ latitude. Water depth in this area is approximately 2700 meters. The age of the crust in the area is 0.5 to $0.9 \mathrm{~m} . \mathrm{y}$. old, as calculated from magnetic anomalies, which give a constant half-spreading rate of $3.5 \mathrm{~cm} / 10^{3} \mathrm{y}$. for the last $2.0 \mathrm{~m} . \mathrm{y}$. The mounds field extends in an east-west direction for approximately $27 \mathrm{~km}$, with most of the mounds occurring in rows or chains, parallel or nearly so to the axial trend of the Galapagos Rift. However, there are also isolated mounds. The height of the mounds varies from less than 1 meter to more than 20 meters; diameters range from 5 to 50 meters. The smaller mounds ( $<4 \mathrm{~m}$ high) have slopes less than $30^{\circ}$, and the higher mounds $(>4 \mathrm{~m})$ have slopes up to vertical (Williams et al., 1979). A shallow moat less than 5 meters deep surrounds many of the mounds (Lonsdale, 1977). Many of the mounds are located above small vertical displacements in the crust, which are presumed to be fracture controlled. Heatflow measurements (Sclater and Klitgord, 1973; Williams et al., 1974; Crane and Normark, 1977), bathymetric and deep-tow surveys (Klitgord and Mudie, 1974; Lonsdale, 1977), and geochemical studies of the hydrothermal vent solutions and dredge hauls (Corliss et al.,

\footnotetext{
${ }^{1}$ Honnorez, J., Von Herzen, R. P., et al., Init. Repts. DSDP, 70: Washington (U.S. Govt, Printing Office).

2 Present address: Saddleback College, Mission Viejo, California.
}

1978,1979 ) have shown that the mounds field and adjacent regions are areas of intense hydrothermal activity. The regional pelagic sediment blanket in the region of the mounds is very thin, ranging from 25 to 35 meters thick (Fig. 2).

\section{Purpose}

The linear and spatial relationships of the Galapagos hydrothermal mounds sediments with the surrounding pelagic oozes needs clarification in order that previous suggestions (Lonsdale, 1977; Natland et al., 1979; Williams et al., 1979; Schrader et al., 1980; Honnorez, Von Herzen, et al., 1981) as to the nature, origin, and threedimensional framework of the hydrothermal sediments can be resolved. The first complete and undisturbed sediment sections in the hydrothermal mounds were drilled on Leg 70 of the Deep Sea Drilling Project, using the newly developed hydraulic piston corer. The purpose of this paper is to present a detailed lithostratigraphic analysis of the Galapagos mounds hydrothermal field and sediments.

As an aid to the reader, a color foldout of selected core sections is included as Plate 2 in the back of this volume (see also the appendix prepared by Chase et al. to the Introduction, Principal Results, and Explanatory Notes, this volume). This plate is referred to throughout this chapter.

\section{SEDIMENTS AND STRATIGRAPHY}

The major sediment types in the mounds field are pelagic oozes and hydrothermal smectites. A complete discussion of these sediment types, their mineralogies and diagenesis is given by Borella et al. (this volume). For completeness a brief description of each sediment type is included here. Color names are based on the G.S.A. Rock Color Chart (1970). 

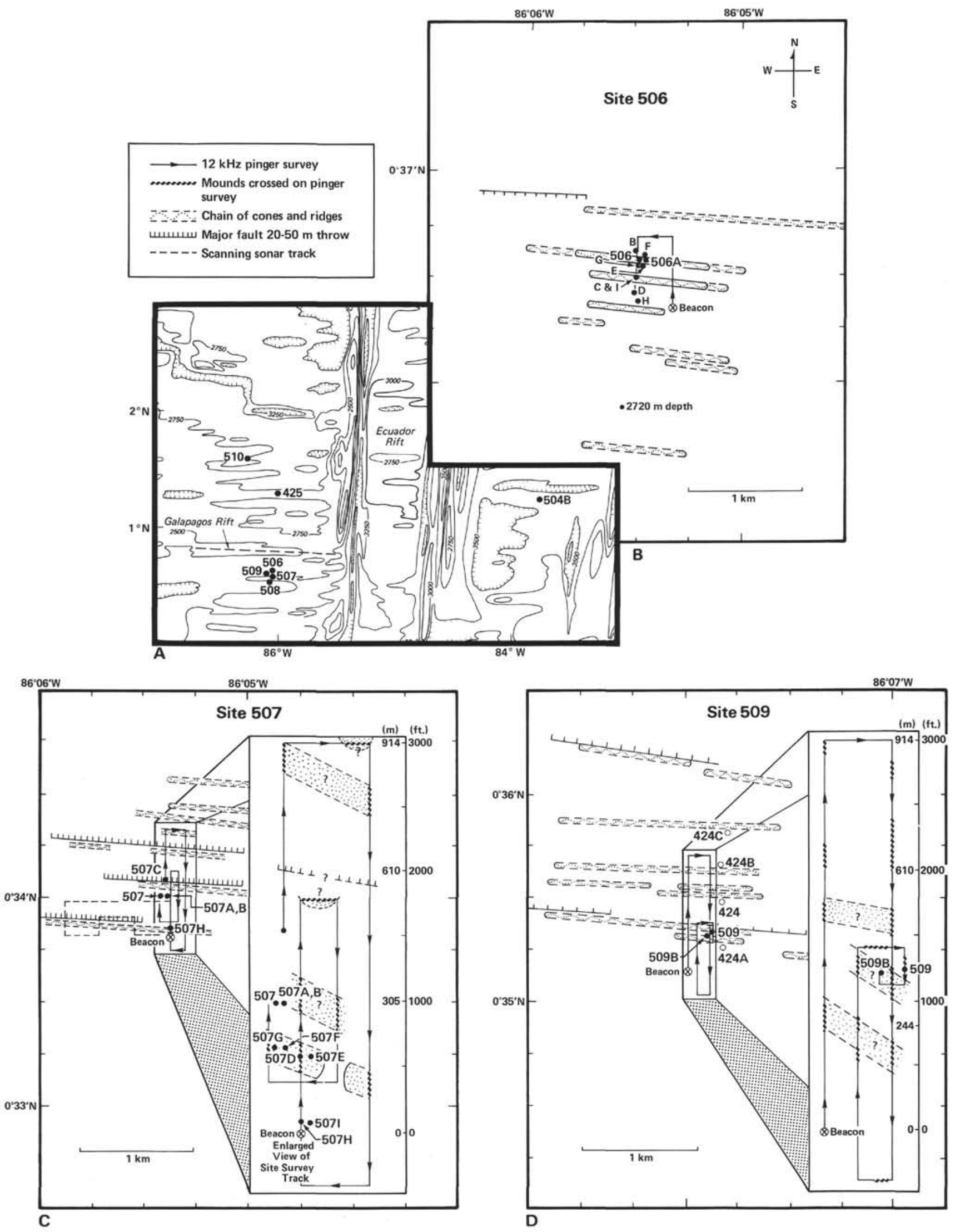

Figure 1. A. General site location map, DSDP Leg 70. B. Detailed survey, Site 506. C. Detailed survey, Site 507. D. Detailed survey, Site 509. 


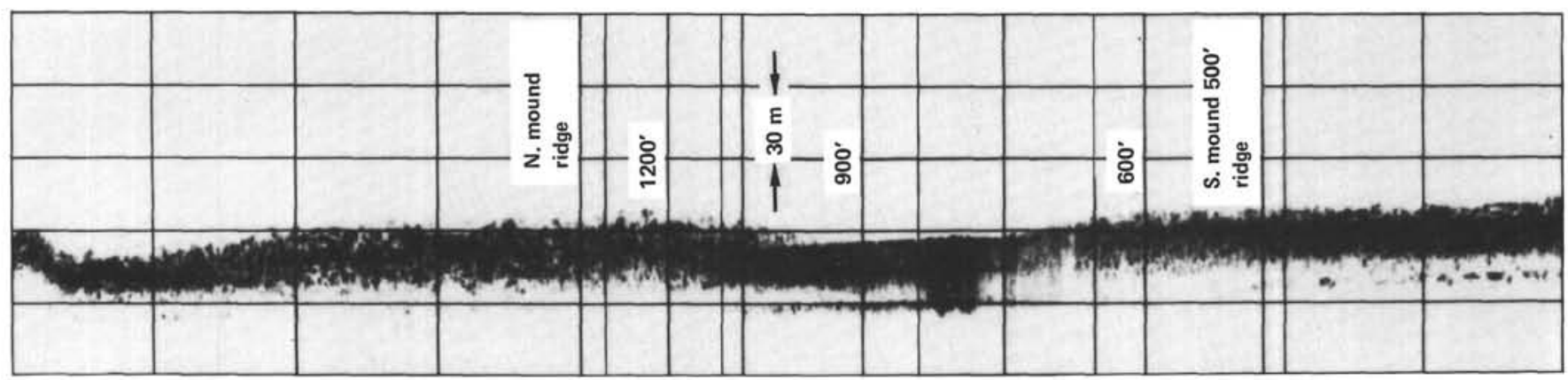

Figure 2. Seismic profile $(3.5 \mathrm{kHz})$ showing the regional sediment thickness and location of two mounds. Note that mounds are identified by lack of internal reflectors.

\section{PELAGIC OOZES}

The pelagic oozes are primarily calcareous nannofossil oozes, containing varying amounts of foraminifers, diatoms, radiolarians, and silicoflagellates (Fig. 3). The oozes are multicolored, with greenish gray to light greenish gray colors dominating (see back pocket foldout, Plate 2). The top section of pelagic sediment in each core is brown to yellow brown (Fig. 4) and is interpreted as indicating the presence of $\mathrm{Fe}$ and $\mathrm{Mn}$ that have migrated upward through the sediments and become oxidized (Lynn and Bonatti, 1965) (see back pocket foldout, Plate 2, Sections 506-1-1 and 506B-9-1). However, the contact between this oxidized surface layer and the underlying greenish gray ooze is fairly sharp (Fig. 4). If this surface layer results from upward migration of $\mathrm{Fe}$ and $\mathrm{Mn}$, one would expect to find gradation contacts between these two units; one would not expect to find any of the oxidized layers preserved below the surface. But at 7 meters sub-bottom, for example, many brown to light brown "oxidized surface layers" are found preserved (see back pocket foldout, Plate 2, Sections 508-23 and 507-2-3). These brown oxidized layers are interpreted to be "relict" surface layers and may indicate changes in sedimentation rates within the Panama Basin over the past thousands to several hundred thousand years.

Further, it seems reasonable to assume that the relict layers are analogous to present conditions on the seafloor. We are presently in an interglacial stage characterized by comparatively low accumulations of carbonate. Arrhenius (1952) first suggested that zones of high carbonate content accumulation represent glacial periods while zones of low carbonate accumulation represent interglacial periods. He attributed this phenomenon to increased current activity and therefore to increased productivity during glacial periods. Hays et al. (1969) and Berger (1973) attribute this relationship to dissolution cycles. Berger and his colleagues (1979) suggest that during the earliest Holocene in the eastern equatorial Pacific the calcium carbonate compensation depth and the lysocline rose drastically. This, combined with a drop in fertility, led to a decrease in sedimentation rates. However, Adelseck and Anderson (1978) suggest that the lysocline in the eastern equatorial Pacific has remained within a few hundred meters of its present depth $(3200 \mathrm{~m})$ for the past $370,000 \mathrm{y}$. The depths of our

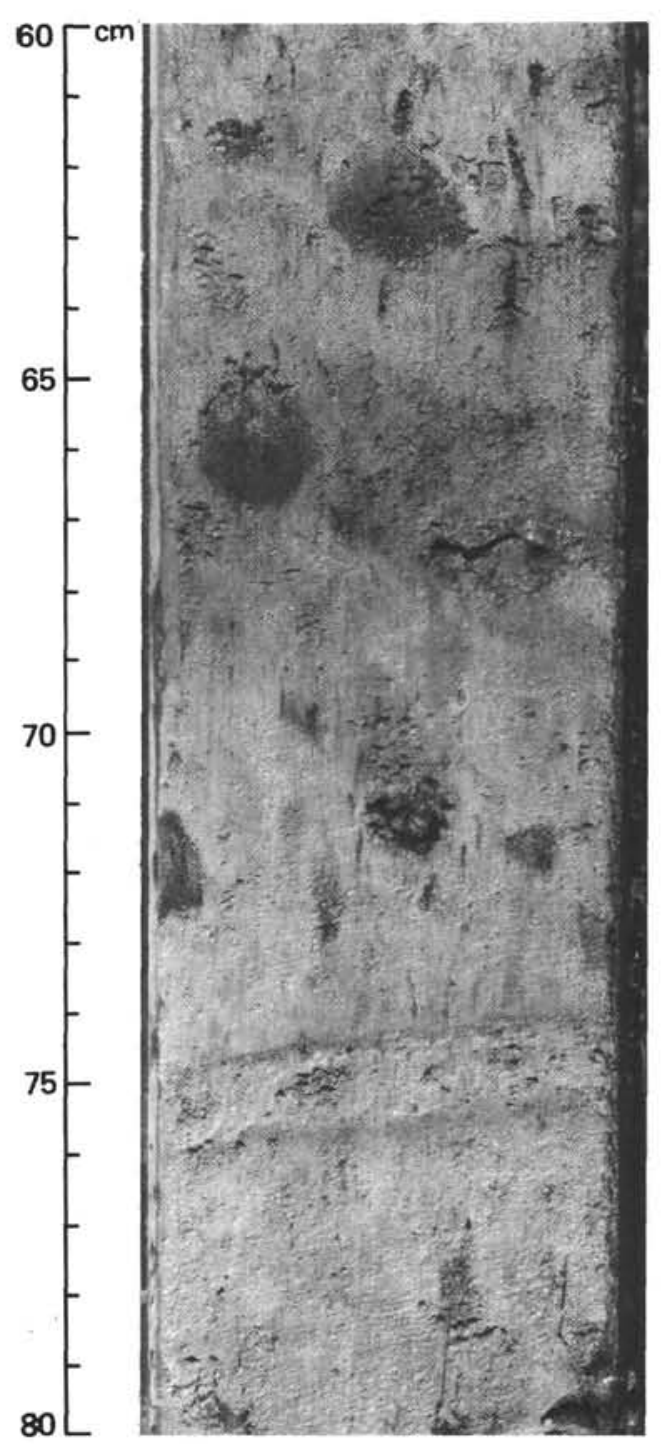

Figure 3. Multicolored, bioturbated pelagic ooze. Note horizontal Zoophycus at $74-76 \mathrm{~cm}$ and rounded circular burrows at $62-66$ $\mathrm{cm}$.

sites are close to this depth $(2750 \mathrm{~m})$. It is obvious that both productivity and dissolution are the major controlling factors for sedimentation of calcium carbonate in the Panama Basin. The influence of dilution by ter- 


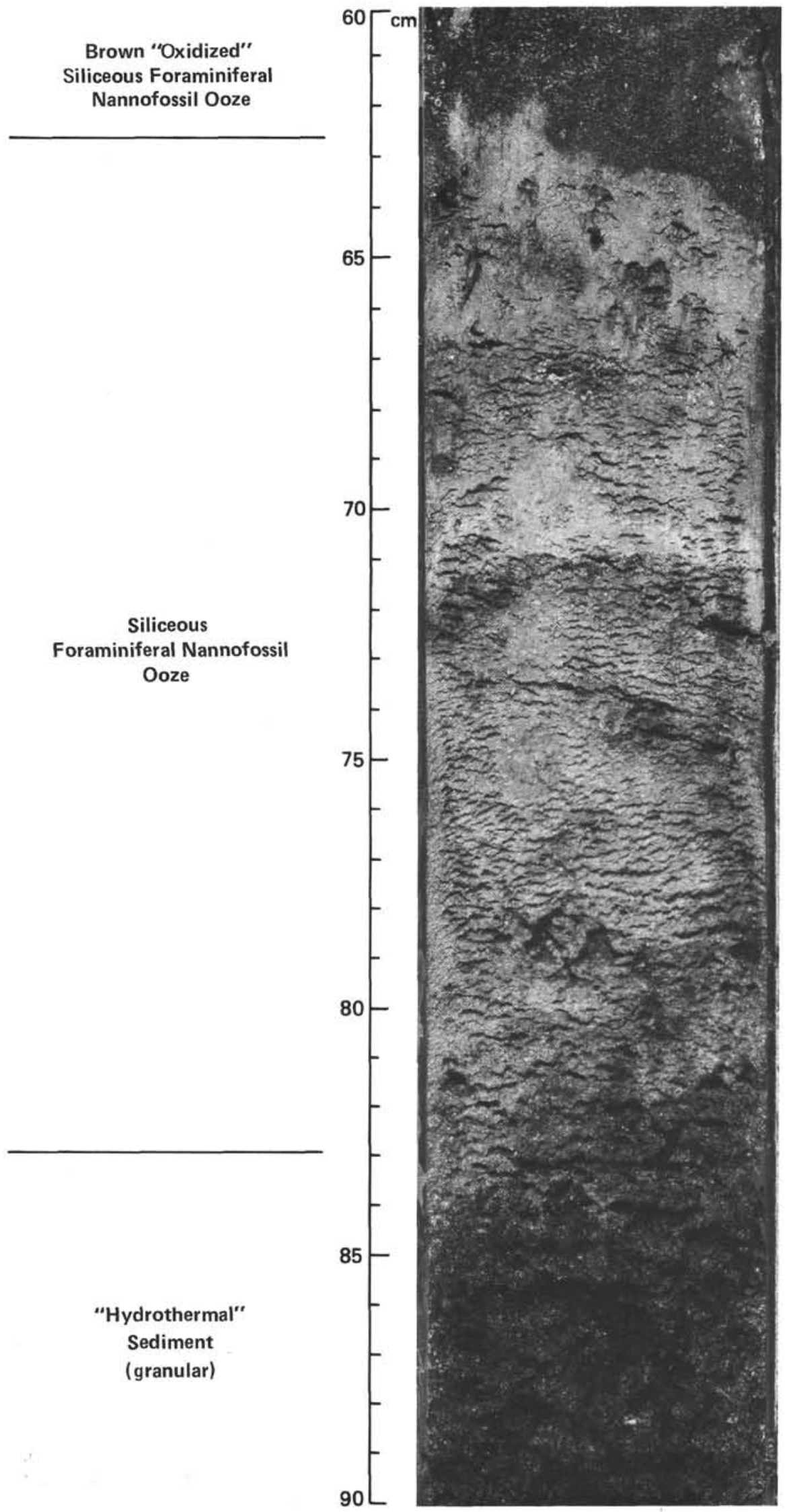

Figure 4. Brown oxidized pelagic sediments overlying normal pelagic sediments, which in turn overlie hydrothermal nontronite (Sample 507D-1-1, 60-90 cm). 
rigenous sediments is a minor factor in the area (Moore et al., 1973).

The colors of pelagic sediments can be influenced by changes in the rate of carbonate sedimentation. If white carbonate material is removed by dissolution, or not deposited, then the remaining sediments will concentrate pigments. I suggest that such is the case here and that the brown color we observe results from two processes. The lack of white carbonate accumulation, reflecting lower sedimentation rates, concentrates pigments and leaves the surface sediments exposed for longer periods of time. The longer exposure allows for the concentration of $\mathrm{Fe}$ and $\mathrm{Mn}$, which have migrated upward from below and are oxidized within these surface sediments (Bonatti and Lynn, 1965). In addition, the longer the surface sediments stay exposed the more susceptible they are to burrowing and boring infauna and bacteria. This biologic ingestion and excretion also can concentrate materials and change the color of the sediment (Figs. 3 and 5).

Some of the "relict oxidized" surfaces can be correlated stratigraphically from hole to hole, e.g., Sections 508-2-3 and 507 H-2-3 (see back pocket foldout, Plate 2, Sections 506-3-2 and 509-3-2). What is so interesting about this particular relict layer is that it is found at $\sim 7$ meters depth sub-bottom. This is the same depth at which Lonsdale (1977) found a strong and persistent internal reflector. Based on the work of Bowles et al. (1973), Lonsdale attributed this reflector and a second one located 15 meters sub-bottom to terrigenous volcanic ash layers. However, no ash layer or volcanic glass was found at 7 meters. Hekinian and Rosendahl (1977) suggest that a single continuous layer of green hydrothermal nontronite causes the reflections. I am suggesting that this relict oxidized layer is responsible for the internal reflection. Variations in acoustic impedance are almost entirely controlled by changes in saturated bulk density (or its inverse, porosity). Changes in saturated bulk density are ultimately caused by climatic changes. Interglacial periods are characterized by low carbonate accumulation and low saturated bulk density, which produce low impedance values (Berger and Mayer, 1978; Mayer, 1979). Other processes that would affect acoustic impedance are variations in mineralogies and diagenetic changes. Within this relict oxidized layer, metalliferous coatings and deposits are recognized (Borella et al., this volume). This variation in chemistry and mineralogy (see Moorby and Cronan, this volume), which is a diagenetic change, along with the low-carbonate accumulation, may be the cause of the reflector at 7-meters depth.

Brownish "relict" surface layers are found at other depths within many of the cores, especially in the offmounds and nonmounds sites; however, no traceable relict layer is found at 15 meters sub-bottom, the depth of a second strong internal reflector observed by Lonsdale (1977). No ash layers are found except for a 4-cm-thick ash layer at 12 meters sub-bottom in Hole 509, but volcanic glass (acidic) was found in minor or trace amounts at approximately 15 meters sub-bottom in smear slides from six cores (Holes 506B,C,D; 507F, H; and 508). It is possible that an ash layer once existed at this depth which has subsequently been destroyed by biologic activity. Alternately, it is possible that the sites we drilled were on the extreme edges of the ash deposits.

\section{BIOGENIC SEDIMENTARY STRUCTURES}

The results of the work of burrowing infauna are present throughout all of the pelagic sediments. The most common ichnogenera present are Zoophycus, Halo burrows (back pocket foldout 508, 2-3; Figs. 5A,B), and circular Planolites(?)-type burrows (Fig. 5C); some open burrows also are observed. Ekdale (1974), van der Lingen (1973), and Warme et al. (1973) describe these trace fossils, along with their geologic ranges and affinities, as belonging to certain sediment types. The burrows are found at all depths and in many instances are cross-cut by younger generation burrows. One large, spectacular, vertical Skolithus(?)-type burrow is present in Section 508-2-3 (back pocket foldout, Plate 2, and Fig. 5A). This burrow is approximately $75 \mathrm{~cm}$ long with an internal lining. It crosscuts many pre-existing burrows and is in turn crosscut by subsequent generation of burrows. At approximately 80 to $82 \mathrm{~cm}$, a horizontal Zoophycus burrow crosscuts the large vertical burrow.

No biogenic sedimentary structures were observed in the hydrothermal nontronite sediments. This may be a result of the granular texture of the hydrothermal sediments in which it is difficult to preserve any track or trail left by a grazing infauna, or it may be that the hydrothermal processes created adverse conditions for these grazing fauna, and they simply migrated away from such sites. The manganese-crust fragments do contain some hollow worm tubes (Fig. 6), and some foraminifers are imbedded in other manganese crusts. However, the manganese crusts that contained these borings and encrustations were mixed with the brown oxidized surface siliceous foraminifer-nannofossil ooze. Bottom photographs taken by the Alvin (Williams et al., 1979) show that the mounds support a dense and active biological community that is concentrated on the hard surface of blocky outcrops and pinnacles. Fecal pellets are present in the hydrothermal nontronite (Borella et al., this volume), but it is not known whether they are the result of a burrowing organism grazing on the nontronitic granules or are pelleted pelagic sediments that have been replaced by nontronite.

\section{HYDROTHERMAL SEDIMENTS}

\section{Manganese-Crust Fragments}

The manganese-oxide crust fragments are brownish black in color, pebble to granule in size, and are flat, angular, and saucer-shaped. Their surface texture is mostly granular, but some hand specimens and thin sections show a botryoidal and concretionary growth pattern. Preliminary investigations using X-ray diffraction (XRD) indicate that todorokite is the dominant manganese oxyhydroxide present, but other amorphous $\mathrm{Fe}, \mathrm{Mn}$ oxide mineral species may also be present which cannot be detected with the X-ray diffraction unit. Color variations within thin sections indicate a diverse mineral as- 


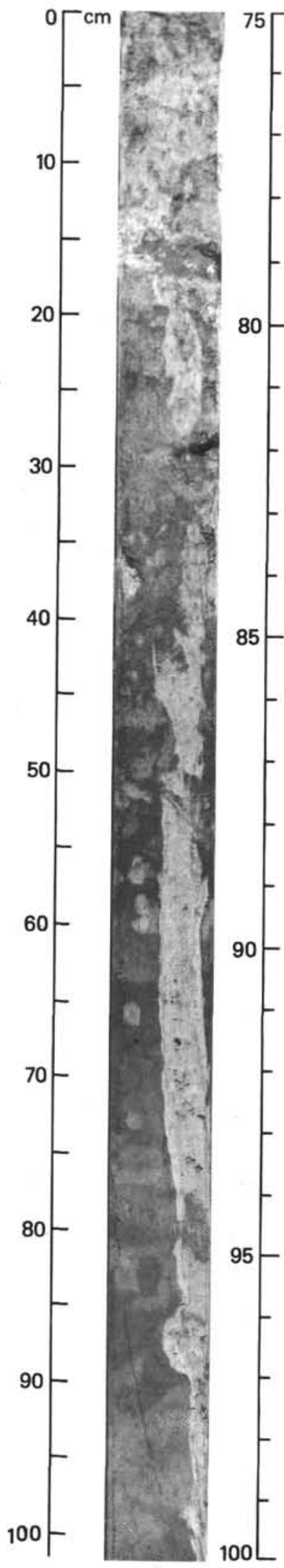

A

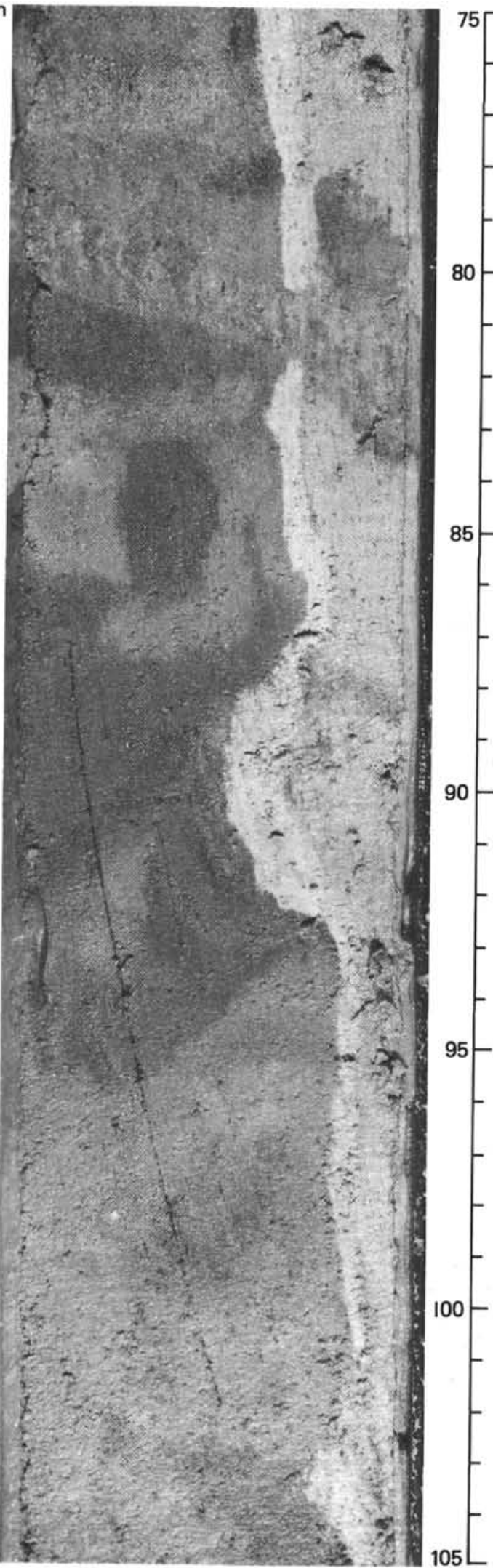

B

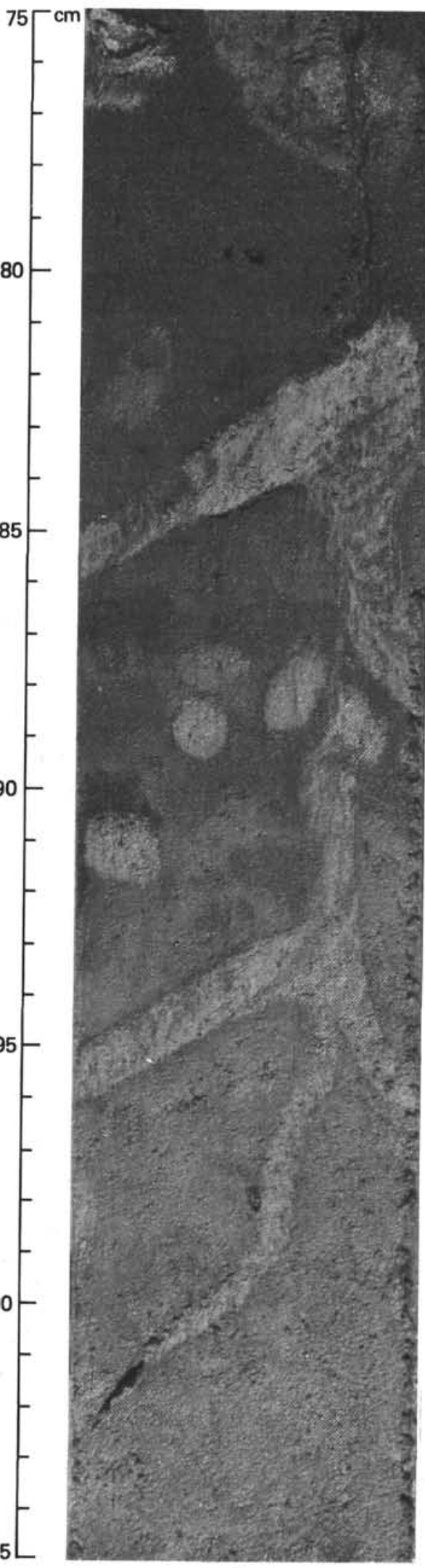

C

Figure 5. Biogenic sedimentary structures. A. Large vertical burrow with internal lining (Skolithus type?) (Section 508-2-3). B. Subhorizontal Zoophycus at $80-82 \mathrm{~cm}$ crosscutting large vertical burrow. Halo burrow at Sample 508-2-3, $83 \mathrm{~cm}$. C. Branching Zoophycus burrows and rounded Planolites(?)-type burrows (Sample 509-3-2, 75-105 cm). 

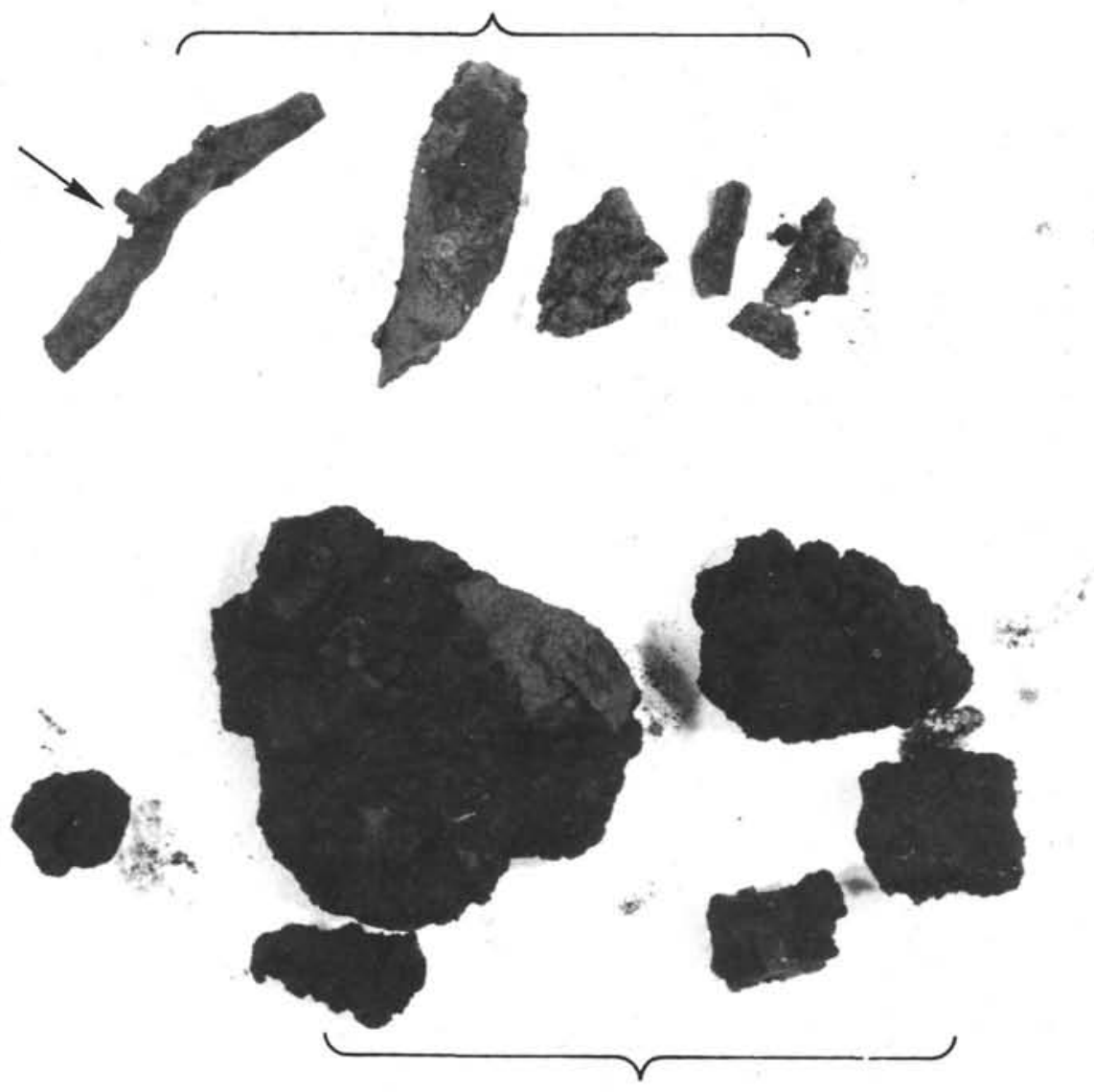

Figure 6. Hollow worm tubes and manganese-crust fragments (Sample 507D-1-1, 14-20 cm).

semblage in these manganese-crust fragments (Borella et al., this volume; Williams et al., 1979).

The manganese-oxide crusts are very localized stratigraphically and are not present in all cores from the mounds area (Fig. 7). When they occur, they are the uppermost hydrothermal sediment and are interspersed within the brown surface oxidized layer or lie beneath as much as 1.4 meters of pelagic ooze. The greatest thickness of manganese-oxide crust fragments is 1.4 meters, which is present in Hole 509B (see back pocket foldout, Plate 2, Section 509B-1-2). At the other sites the thickness of the manganese-oxide crust fragments is only a few centimeters. It is possible that we did not drill right on the top of the mounds, because bottom photographs (Williams et al., 1979) show that the blocky outcrops and knobs on the mounds are composed of amorphous $\mathrm{Fe}$ oxides, manganese-rich birnessite and todorokite, and semilithified Fe-rich nontronite. However, most of the mounds observed by Alvin (Williams et al., 1979) were generally covered with unlithified sediment, which is the normal biogenic sediment of the region. The Mnrich crusts were barely visible through the partial covering of pelagic sediments. This agrees quite nicely with our observations from the cores drilled on Leg 70 . The manganese-crust fragments are confined just to the mounds and are not continuous in any direction away from the mounds. Thus, the suggestion by Schrader et al. (1980) that the Mn content in the mounds field may exceed $1 / 13$ of the world's stockpile is grossly in error. The manganese oxides are not 6 meters thick and are not continuous for $1 \mathrm{~km}$; they are no more than 2 meters thick and extend most likely for no more than 10 meters in any direction.

\section{Green Nontronitic Clay Granules}

Megascopically, the nontronite is green to greenish black and forms friable to semiconsolidated angular grains, ranging in size from 1 to $20 \mathrm{~mm}$ (Fig. 8A). The grains can be easily crushed between the fingers. Occasionally, yellow and orange colors occur which may indicate oxidizing conditions (back pocket foldout, Plate 2 , Section 509B-2-2). Texturally, the nontronite ranges in grain size from very coarse sand to pebbles, but it also appears as a finer-grained, silt- to clay-sized compact sediment (Fig. 8B and back pocket foldout, Plate 2, Section 507D-6-3). This compact variety is lighter in color and usually is found in or near gradational contacts separating the granular nontronite from the pelagic oozes. 


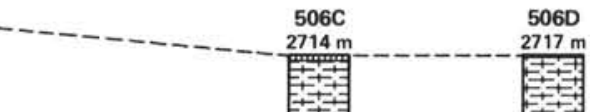

M M M crust fragments

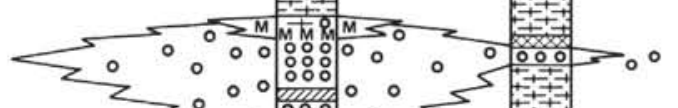

盂而而 Surface oxidized layer

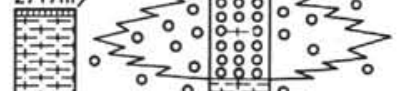

Basalt clasts and basement

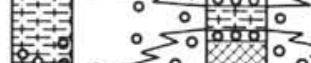

1.

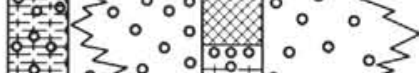

政

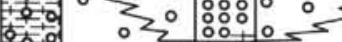

연

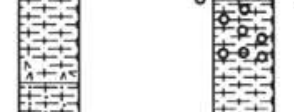

त्रता

trat $\circ 0^{\circ} \circ 888.0$

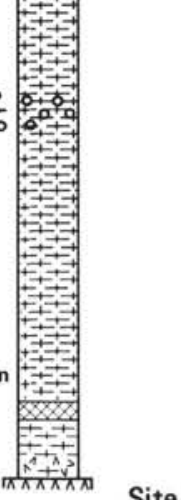

VIIIII Void (in surface core)

Not recovered

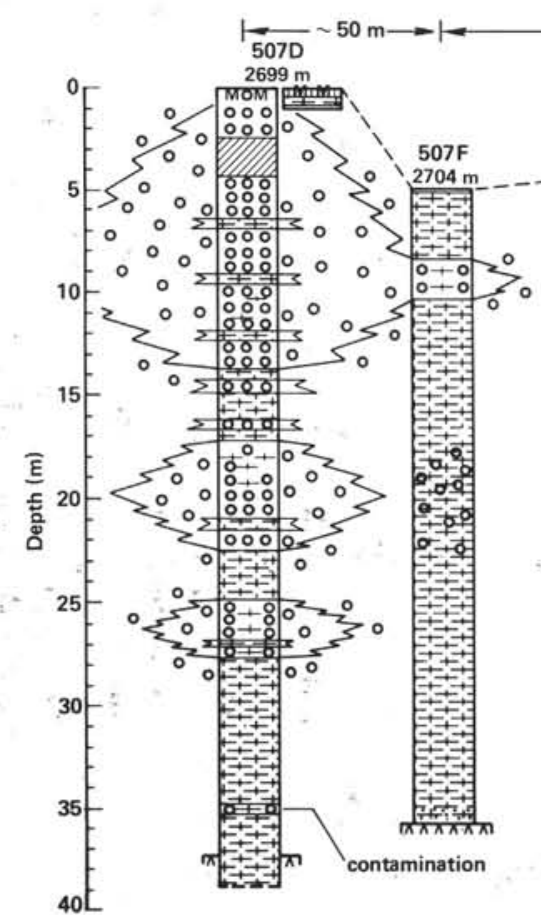

Site 507

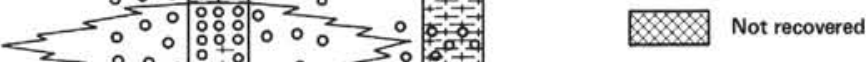

Figure 7. Stratigraphic relationships among and between mounds sediments. 


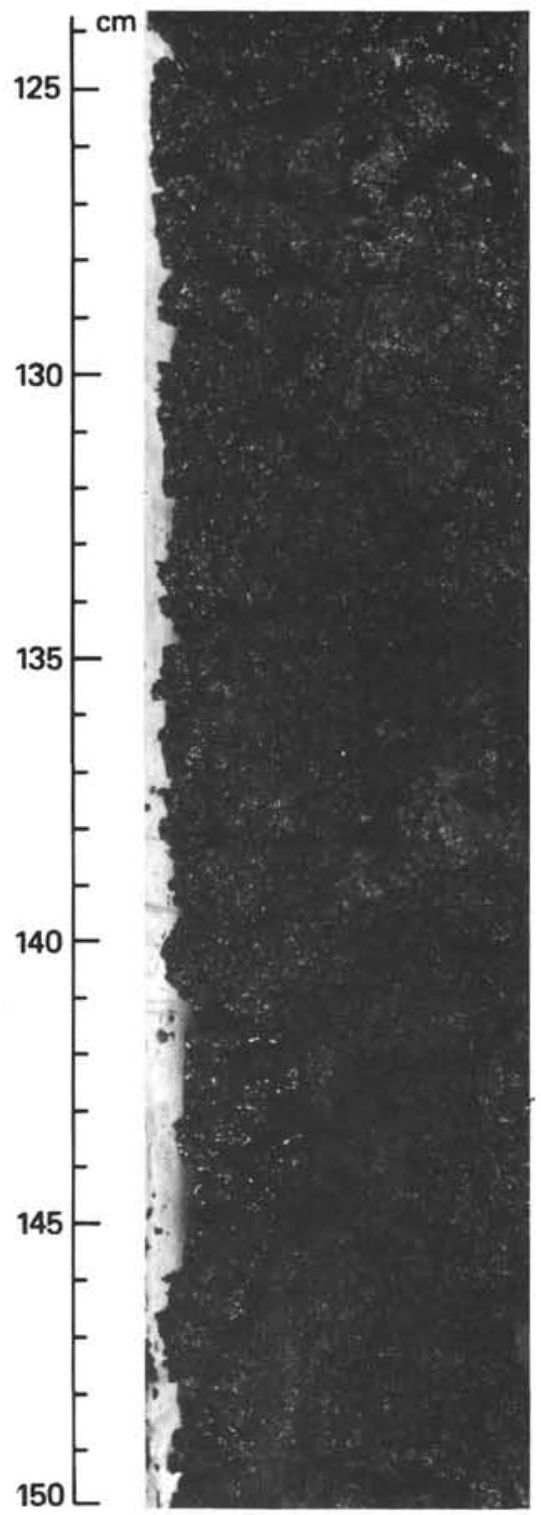

A

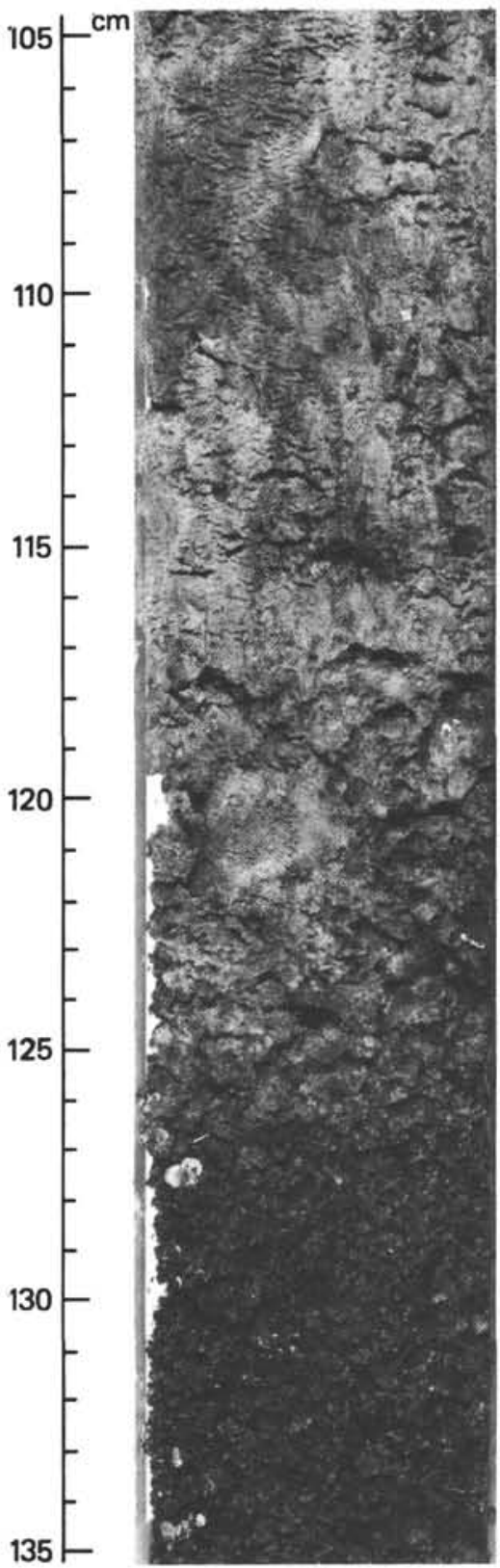

B

Figure 8. Examples of granular and compacted hydrothermal sediment. A. Sample 509B-1-2, $125-150 \mathrm{~cm}$. B. Sample 509B-3-2, 105-135 cm.

Sometimes the finer-grained nontronite is observed interstratified between coarse granular hydrothermal clay. A detailed discussion of the petrology of the hydrothermal nontronite is given by Borella et al. (this volume).

The contacts between the hydrothermal sediments and pelagic sediments are mostly gradational (see back pocket foldout and Fig. 9A), but sharp contacts also are observed (Fig. 9B). In Hole 509B the contact between the manganese-oxide crust layer and the nontronitic clay is fairly well defined (back pocket foldout, Plate 2, Section 509B-1-2). More commonly, the manganese-oxide crusts are dispersed throughout the pelagic sediments, which in turn lie on top of the hydrothermal sediments.

Stratigraphically the nontronite is confined to the upper half to two-thirds of the cores (Fig. 7) and is mixed and stratified with pelagic oozes which are depleted of their siliceous microfossil content (see site summaries, this volume). Evidence also has been presented by Borella et al. (this volume), Bender (this volume), and Moorby and Cronan (this volume) that these pelagic sediments are being dissolved, and nontronite deposited in their place by hydrothermal processes. Recovered thickness of the hydrothermal nontronite from the mounds sites (Holes 506, 506C, 507D, and 509B) varies from 9.0 to approximately 16 meters. Two off-mounds sites (Holes 506D and 507F) had two thin nontronite layers of 0.9 and 1.8 meters, respectively (Fig. 7). The lateral extent of the nontronite is apparently confined to the mounds proper, where the thickest accumulations occur. Away from the mounds the nontronite thins rap- 


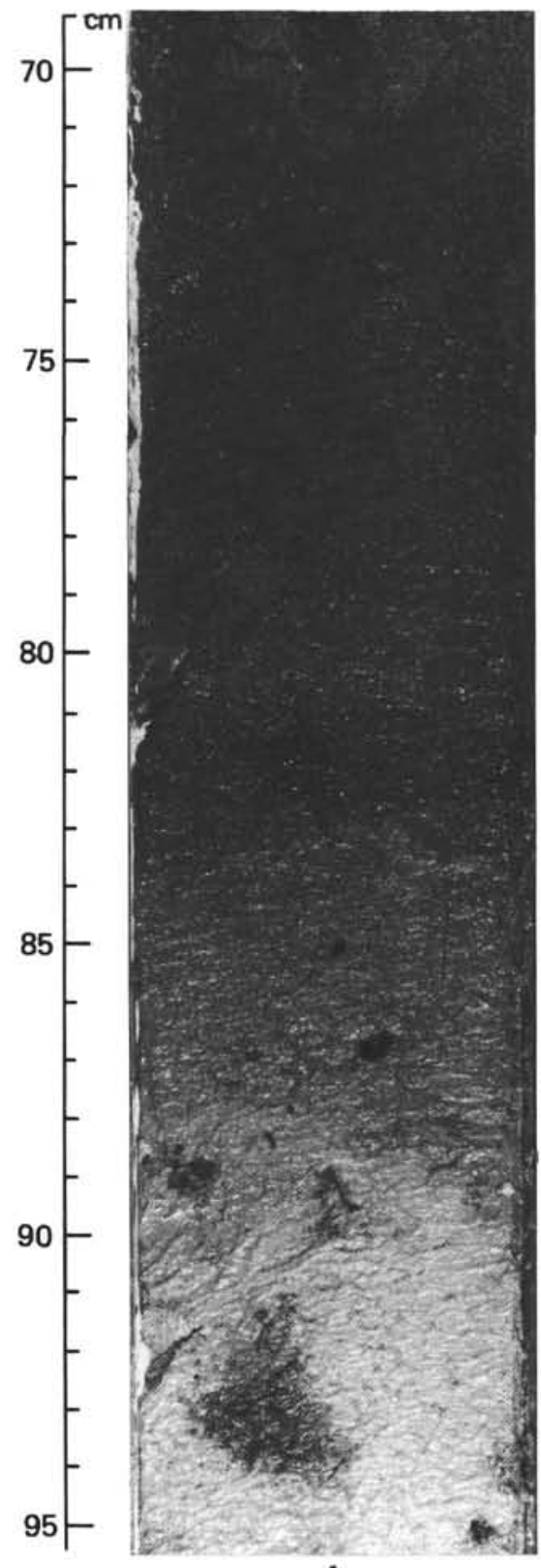

A

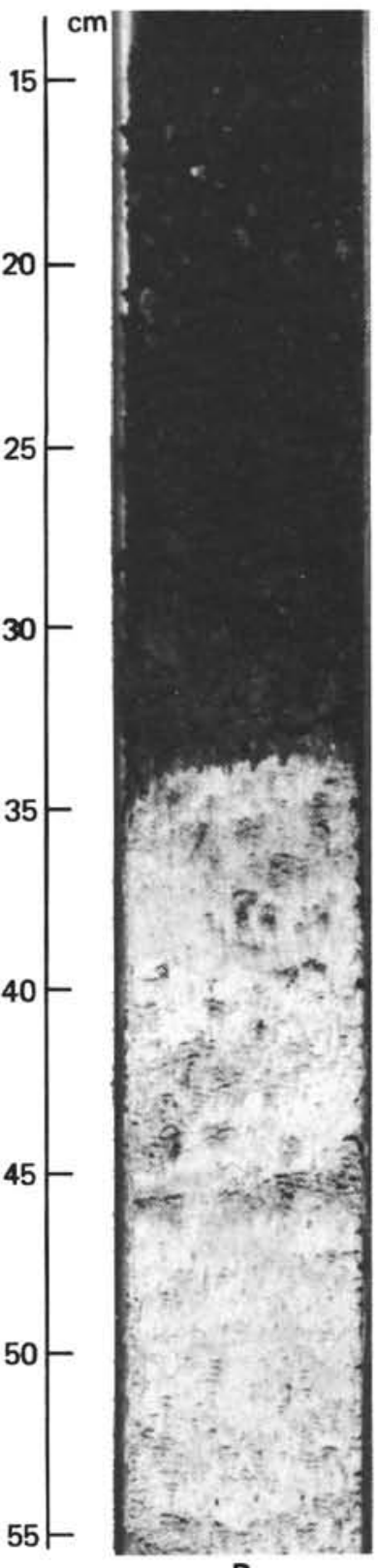

B
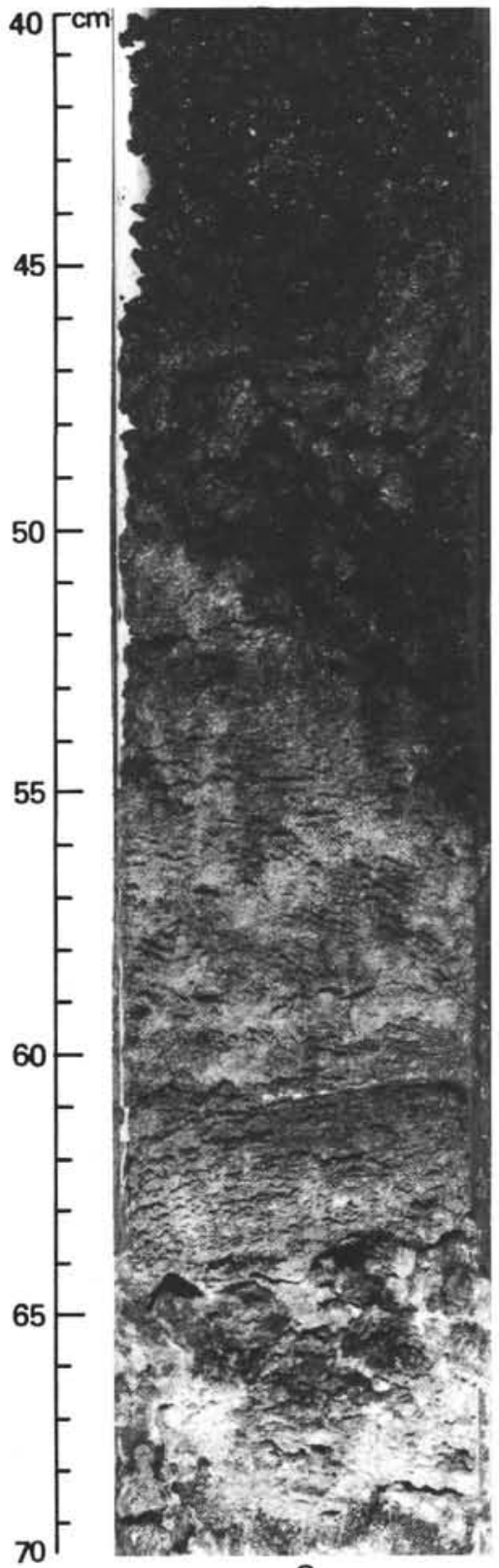

C

Figure 9. A. Gradational contact between hydrothermal and pelagic sediments (Sample 506D-2-3, 70-95 cm). B. Sharp contact between hydrothermal and pelagic sediments (Sample 506C-5-1, 30-40 cm). C. Pelagic sediment overlying transitional hydrothermal and pelagic sediments, which in turn overlies hydrothermal granules (Sample 509B-3-2, 40-70 cm).

idly, with the furthest extension of nontronitic layers being approximately 50 to 60 meters. No regional layer of hydrothermal sediment exists (Natland et al., 1979).

It is interesting that in several mounds and offmounds cores, zones of nontronite-rich mottles are present (Fig. 7). On the mounds these mottled zones occur between nontronite layers and just below the last coherent nontronite unit. The frequency of these green mottles decreases rapidly with depth in the holes, to the point where they are completely absent for several meters above the basement. In the off-mounds sites the nontronite mottle zones are not associated with any definite layer, but they are stratigraphically in a position which can be laterally traced to a hydrothermal layer found in the immediately adjacent mound. This suggests that the hydrothermal solutions are invading and cannibalizing the surrounding host sediment in all directions and are extracting the necessary elements for precipitation of nontronite. A discussion of the chemical reactions taking place within the sediments is presented by Honnorez et al. (1981) and Bender (this volume). The nontronitic mottle zones are not found beyond 60 meters from a given mound. The continual cannibalizing of the host sediment is naturally dependent on the availability of hydrothermal solution, which is directly associated with hydrothermal activity on a mound and the presence of 
oxygenated waters. The avenue for the migration of these fluids is well established, because the hydrothermal nontronite is very porous and permeable. This is further supported by the exotic yellow and orange (oxidized) zones found in the nontronitic sediments. This continual consumption of the host sediments also explains why the best examples of partially dissolved and replaced microfossils occur in the transition zones and in the nontronite mottles (Borella et al., this volume). As this dissolution process continues, all of the host sediment is eventually dissolved or replaced by nontronite; few ghost structures are preserved.

In comparing the thickness of accumulated pelagic oozes on the mounds to that of those recovered immediately off the mounds it becomes apparent that the pelagic oozes expected on the mounds do not occur. For example, Hole 506, on a mound, has approximately 11.5 meters of recovered pelagic ooze. It neighbors Hole 506B, located approximately 50 meters away on a relatively flat seafloor, which has 20.5 meters of recovered pelagic sediment; hence as much as 9 meters of pelagic sediments may be missing from the mound site. The most likely explanation for this discrepancy is that the pelagic sediments are being dissolved and replaced by hydrothermal solutions and minerals. The presence of a moat around many mounds (Lonsdale, 1977) may represent the effect of dissolution of pelagic sediment.

Alternatively, pelagic sediments that accumulate on the mounds may slump off them onto adjacent areas of the seafloor, increasing the sedimentary thickness in these areas. No slump structures were observed in the recovered cores, but Williams et al. (1979), from direct observations of mounds with the Alvin, cite evidence for both slumping and erosion on the steep-sided older mounds. The smaller mounds do not generally have steep slopes, and they show little evidence of erosion. However, there are no direct observations of pelagic sediments accumulating around the mounds (Williams et al., 1979); in fact, as mentioned, many of the larger mounds are surrounded by a moat (Lonsdale, 1977). If slumping is occurring, it has little effect on the surrounding environment.

Bottom currents also could be responsible for dusting off the mounds surfaces, but the results of Legs 70 and 54 , along with observations by Williams et al. (1979), indicated that the upper surfaces of the mounds consist of pelagic sediments. In addition, the continuous brown oxidized surface zone is approximately the same thickness both on and off the mounds (Fig. 8 and back pocket foldout, Holes 506, 506B). The presence of a traceable relict oxidized zone at 7 meters sub-bottom suggests that slumping is minor.

\section{GENERAL STRATIGRAPHIC RELATIONSHIPS OF THE MOUNDS SEDIMENTS}

The sediments recovered at each mounds site can be divided stratigraphically into three units (Fig. 10). Unit I, the uppermost layer, is composed of siliceous foraminifer-nannofossil oozes. The upper section of this unit is the brown oxidized zone that overlies the "normal" regional pelagic ooze. The lower boundary of Unit $\mathrm{I}$ is the first occurrence of a hydrothermal sediment layer, whether it be manganese-oxide crusts or green nontronitic clay grains. The thickness of Unit I varies

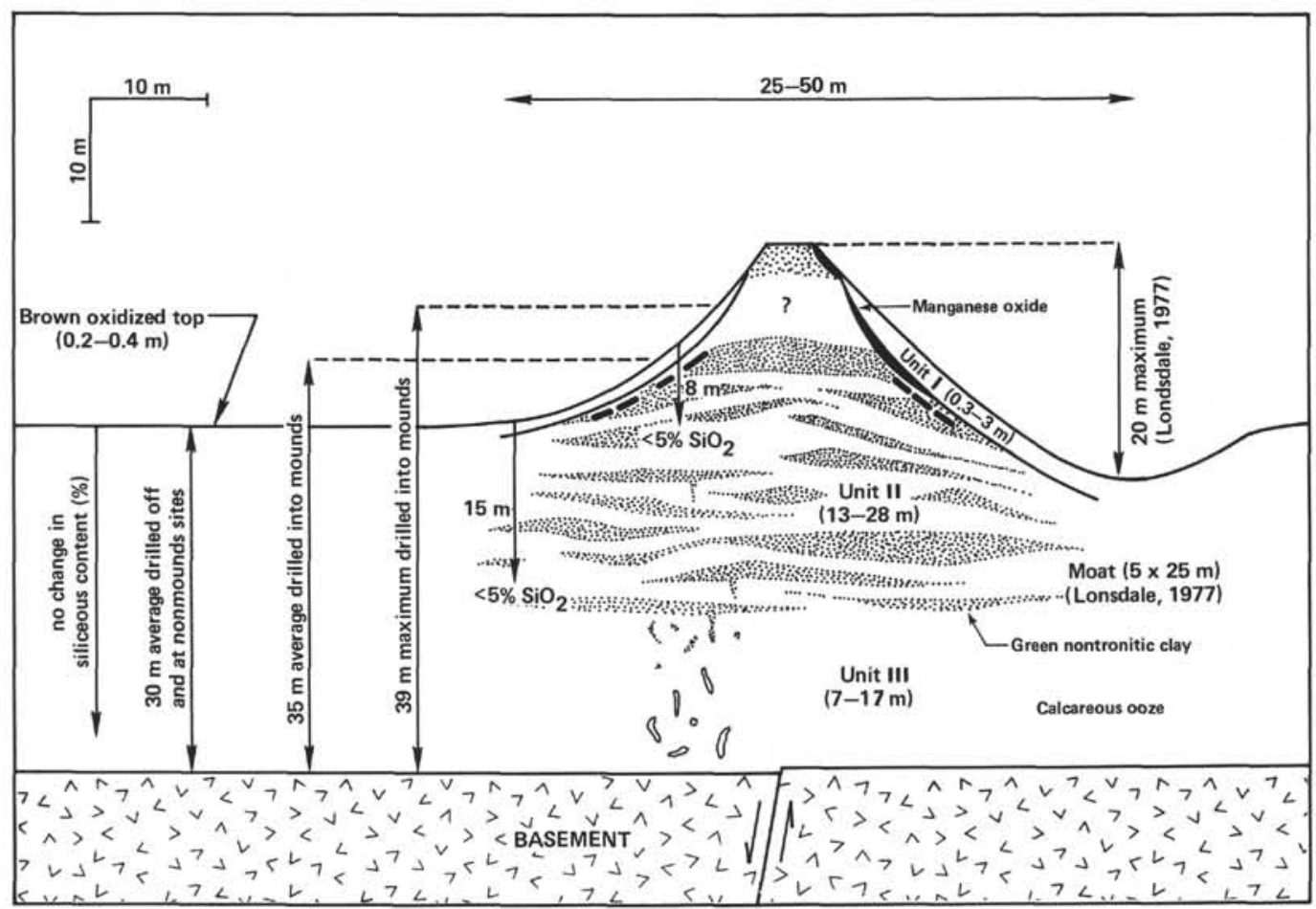

Figure 10. Idealized diagram of the internal structure and dimensions of a mound. (Reprinted from Geol. Soc. Am. Bull., Pt. 1, Vol. 92.) 
from 0.3 to 3.0 meters. Sometimes manganese-oxide crust fragments are disseminated throughout Unit I, but they do not form any definite layer.

Unit II consists of interbedded and mixed hydrothermal sediments and pelagic oozes. The thickness of this interval on the mounds ranges from 13 to 28 meters (Fig. 10). Nontronitic clay is the uppermost hydrothermal sediment except in Hole 509B, where a 1.4-meterthick layer of manganese-oxide crust fragments is present. The contacts between the hydrothermal sediments and the pelagic oozes is gradational, with the more compact green nontronite constituting the transitional materials. Laterally, at all sites, the hydrothermal sediment thins rapidly away from the mounds; only two thin layers of approximately 1 and 2 meters thickness and some nontronitic mottled zones occur as far as 50 to 60 meters from the mounds.

The siliceous fossil content in the pelagic sediments within Unit II on the mounds always drops below 5\% approximately 12 meters below the mudline. This reduction in siliceous fossil content occurs between 10 meters and 27 meters in the off-mounds sites. The sediments from Sites 508 and 510 show no reduction at all in siliceous microfossil content.

Unit III, the lowermost unit in the mounds area, is composed of foraminifer-nannofossil oozes. Thickness varies from 7 to 17 meters; the upper contact is gradational with the hydrothermal smectite, and the lower boundary is the sediment/basement contact. Nontronite-rich mottles occur immediately beneath this last hydrothermal layer and extend downward 1 to 6 meters. Preservation of trace fossils in this unit is good. Some brown "relict" surface layers also occur in Unit III. What is interesting is that some of these relict layers are located in the nontronite mottle zone, but they themselves are free or relatively free of nontronitic mottles. Quite possibly diagenetic effects have concentrated the darker elements and coated the existing pelagic sediments. This, along with low carbonate accumulation, has decreased the porosity, or increased the wet-bulk density, and prevented hydrothermal solutions from reacting with the brown pelagic sediments at the same rate as with "normal" pelagic oozes.

\section{CONCLUDING REMARKS}

Based on the stratigraphic evidence presented, the following conclusions can be made.

1) The hydrothermal sediments are localized and restricted both vertically and laterally within the mounds area. The strata composed of nontronitic clay granules are thickest on the mounds proper and thin away from the mounds rapidly. Thin layers and nontronitic mottled zones can be traced laterally for distances of approximately 60 meters. No nontronite is found beyond this distance. Thus no regional hydrothermal sediment blanket exists in the area we drilled. This is contrary to the suggestions of Natland et al. (1979) and Rosendahl and Hekinian et al. (1980).

2) Manganese-oxide crust fragments are even more localized than the nontronite. They are very thin and do not form any continuous layer. It is very unlikely that
$1 / 13$ of the world's stockpile of manganese is located in the mounds area as was suggested by Schrader et al. (1980).

3) The presence of a 7- to 17-meter-thick layer of pelagic ooze between basement and the hydrothermal sediments indicates that hydrothermal activity commenced after a regional sediment blanket was deposited. The reason for this is discussed by Becker et al. (this volume) and by Hekinian et al. (1980).

4) The interstratification of hydrothermal sediments with pelagic oozes on the mounds indicates that hydrothermal activity is episodic. It cannot be determined for certain that the holes drilled on Leg 70 were directly on a mound crest. Evidence from the Alvin dives (Williams et al., 1979) suggests that some mounds are presently active while others are not, indicating an episodic nature in the mounds field development.

5) The lack of pelagic sediments in the mounds compared to the off-mounds sites, the decrease in siliceous microfossil content in the pelagic sediments that are mixed and interbedded with the hydrothermal sediments, the presence of gradational boundaries between nontronitic and pelagic sediment layers, and the nontronitic mottled zones present in areas adjacent to hydrothermal layers, both vertically and laterally, suggest that hydrothermal solutions are continually invading and cannibalizing the host pelagic sediment. Partial dissolution and replacement of microfossils (Borella et al., this volume), pore-water chemistry (Bender, this volume), and sediment geochemistry (Moorby and Cronan, this volume) further suggest that the hydrothermal activity is occurring within the sediments, the end result being the deposition of hydrothermal minerals in place of the regional pelagic sediments. Replacement and dissolution of pre-existing sediment along with direct formation of nontronite from hydrothermal solutions interacting with seawater account for the distribution of sediments in a mound.

6) "Relict" brown oxidized layers occur within the pelagic oozes. These zones represent a period of low carbonate accumulation (interglacial?), which led to longer periods of exposure of sediments at the surface, and permitted longer periods for $\mathrm{Fe}$ and $\mathrm{Mn}$ to migrate to the surface zone and be oxidized. A relict brown oxidized layer at 7 meters sub-bottom can be correlated from hole to hole. It is suggested that this is the prominent regional acoustic reflector reported by Lonsdale (1977). The combination of low carbonate accumulation and enrichment of diagenetic $\mathrm{Fe}$ and $\mathrm{Mn}$ in this zone may be responsible for altering acoustic impedance.

\section{ACKNOWLEDGMENTS}

Professor Robert H. Osborne, University of Southern California, and Dr. James H. Natland, Scripps Institution of Oceanography, critically reviewed this manuscript.

My special thanks to the Leg 70 shipboard party for their valuable discussions and contributions, many of which are incorporated into this manuscript. Lola Boyce kindly typed and edited all versions of the manuscript.

I would like to thank Riverside City College for providing part of my salary during a sabbatical leave year in which most of this work was completed. 


\section{REFERENCES}

Adelseck, C. G., and Anderson, T. F., 1978. The late Pleistocene record of productivity fluctuations in the eastern equatorial Pacific Ocean. Geology, 13:251-266.

Arrhenius, F., 1952. Sediment cores from the East Pacific. Rept. Swedish Deep Sea Expedition, 1947-1948, 5:1-228.

Berger, W. H., 1973. Deep sea carbonates: Pleistocene dissolution cycles. J. Foraminiferal Res., 3:187-195.

Berger, W. H., Ekdale, A. A., and Bryant, P. P., 1979. Selective preservation of burrows in deep-sea carbonates. Mar. Geol., 32: 205-230.

Berger, W. H., and Mayer, L. A., 1978. Deep sea carbonates: Acoustic reflectors and lysocline fluctuations. Geology, 6:11-15.

Bonatti, E., Fisher, D. E., Joensuu, O., and Rydell, H. S., 1971. Postdepositional mobility of some transition elements, phosphorous, uranium and thorium in deep sea sediments. Geochim. Cosmochim. Acta, 35:189.

Bowles, F. A., Jack, R. N., and Carmichael, I. S., 1973. Investigation of deep-sea volcanic ash layers from equatorial Pacific cores. Geol. Soc. Am. Bull., 84:2371.

Corliss, J. B., Dymond, J. R., Gordon, L. I., Edmond, J. M., Von Herzen, R. P., Ballard, R. D., Green, K., Williams, D. L., Bainbridge, A., Crane, K., and van Andel, Tj. H., 1979. Submarine thermal springs on the Galapagos Rift. Science, 203:1073-1083.

Corliss, J. B., Lyle, M., Dymond, J. R., and Crane, K., 1978. The chemistry of hydrothermal sediment mound deposits near the Galapagos Rift. Earth Planet. Sci. Lett., 40:12-24.

Crane, K., and Normark, W. R., 1977. Hydrothermal activity and crestal structure of the East Pacific Rise at $21^{\circ} \mathrm{N}$. J. Geophys. Res., 82:5336-5348.

Ekdale, A. A., 1974. Geologic history of the abyssal benthos: Evidence from trace fossils in Deep Sea Drilling Project cores [Ph.D. dissert.]. Rice Univ., Houston.

Hays, J. D., Saito, T., Opdyke, N. D., and Burckle, L. H., 1969. Pliocene-Pleistocene sediments of the equatorial Pacific: Their paleomagnetic, biostratigraphic and climatic record. Geol. Soc. Am. Bull., 80:1481-1514.

Hekinian, R., and Rosendahl, B. R., 1977. In the East Pacific: Challenger completes 54 cruise. Geotimes, 22:19-23.

Hekinian, R., Rosendahl, B. R., and Natland, J. H., 1980. Ocean crust geothermal processes: A perspective from the vantage of Leg 54 drilling. In Rosendahl, B. R., Hekinian, R., et al., Init. Repts. DSDP, 54: Washington (U.S. Govt. Printing Office), 395-422.

Honnorez, J., Von Herzen, R. P., Barrett, T. J., Becker, K., Bender, M. L., Borella, P., Hubberten, H.-W., Jones, S. C., Karato, S., Laverne, C., Levi, S., Migdisov, A. A., Moorby, S. A., and
Schrader, E. L., 1981. Hydrothermal mounds and young ocean crust of the Galapagos: Preliminary Deep Sea Drilling results, Leg 70. Geol. Soc. Am. Bull., 92, Pt. I:457-472.

Klitgord, K. D., and Mudie, J. D., 1974. The Galapagos Spreading Center: A near-bottom geophysical survey. Geophys. J. $R$. Astron. Soc., 38:563-586.

Lonsdale, P., 1977. Deep-tow observations at the mounds abyssal hydrothermal field, Galapagos Rift. Earth Planet. Sci. Lett., 36: 92-110.

Lynn, D. C., and Bonatti, E., 1965. Mobility of manganese in diagenesis of deep-sea sediment. Mar. Geol., 3:457-474.

Mayer, L. A., 1979. Deep sea carbonates: Acoustic physical and stratigraphic properties. J. Sediment Petrol., 49(3):819-836.

Moore, J. C., Heath, R. G., and Kowsmann, R. O., 1973. Biogenic sediments of the Panama Basin. J. Geol., 81:458-472.

Natland, J., Rosendahl, B., Hekinian, R., Dmitriev, Y., Fodor, R., Goll, R., Hoffert, M., Humphris, S., Mattey, D., Petersen, N., Roggenthen, W., Schrader, E., Srivastava, R., and Warren, N., 1979. Galapagos hydrothermal mounds: Stratigraphy and chemistry revealed by deep sea drilling. Science, 204:613-616.

Rosendahl, B. R., Hekinian, R., et al., 1980. Init. Repts. DSDP, 54: Washington (U.S. Govt Printing Office).

Schrader, E. L., Furbish, W. J., Mattey, D., and May, J. A., 1980. Geochemistry and carbonate petrology of selected sediment samples from Deep Sea Drilling Project, Leg 54, East Pacific. In Rosendahl, B. R., Hekinian, R., et al., Init. Repts. DSDP, 54: Washington (U.S. Govt. Printing Office), 319-329.

Sclater, J. G., and Klitgord, K. D., 1973. A detailed heat flow, topographic and magnetic survey across the Galapagos Spreading Center at $86^{\circ}$ W. J. Geophys. Res., 78:6951-6975.

van der Lingen, G. J., 1973. Ichnofossils in deep cores from the Southwest Pacific. In Burns, R. E., Andrews, J. E., et al., Init. Repts. DSDP, 21: Washington (U.S. Govt. Printing Office), 693-700.

Warme, J. E., Kennedy, W. J., and Schneidermann, N., 1973. Biogenic sedimentary structures (trace fossils) in Leg 15 cores. In Edgar $\mathrm{N}$. T., Saunders, J. B., et al., Init. Repts. DSDP, 15: Washington (U.S. Govt. Printing Office), 813-831.

Williams, D. L., Green, K., van Andel, Tj. H., Von Herzen, R. P., Dymond, J. R., and Crane, K., 1979. The hydrothermal mounds of the Galapagos Rift: Observations with DSRV Alvin and detailed heat-flow studies. J. Geophys. Res., 84(B13):7467-7484.

Williams, D. L., Von Herzen, R. P., Sclater, J. G., and Anderson, R. N., 1974. The Galapagos Spreading Center: Lithospheric cooling and hydrothermal circulation. Geophys. J. R. Astron. Soc., 38: 587-608. 